\title{
Risky closeness and distance in two fieldwork sites in Brazil
}

\section{Andreza Aruska de Souza Santos}

School of Anthropology \& Museum Ethnography, University of Oxford, Oxford, United Kingdom

Address: 58 Banbury Road, COMPAS - University of Oxford, Oxford OX2 6QS

Email: andreza.desouzasantos@compas.ox.ac.uk

http://www.anthro.ox.ac.uk/people/dr-andreza-de-souza-santos

Phone: 00447501819464

Dr Andreza Aruska de Souza Santos is a Post-Doctoral Researcher at the School of Anthropology \& Museum Ethnography, at the University of Oxford. With a focus on urban ethnography, Andreza incorporates themes of cultural heritage, informal housing, infrastructure, participatory city planning, social memory and migration into her work. As part of the Urban Transformations Portfolio, she also coordinates cities research projects in Brazil, China, South Africa and India funded by the ESRC. Before arriving in Oxford, she obtained her PhD in Social Anthropology at the University of St Andrews, an MA in Social Sciences at the University of Freiburg, University of KwaZulu Natal and Jawaharlal Nehru University, and a BA in Political Science at the University of Brasilia. 


\section{Abstract}

This article discusses how closeness and distance affected my ethnographic research in two Brazilian cities. I first address the pitfalls I encountered researching the Luz region, a run-down transportation hub and residential area in São Paulo's city centre, also known as Crackland for its drug trade and consumption. In Luz I was confronted with everyday hostility in an environment of unknown others and an ever-changing cityscape: users of cultural offerings, temporary residents and by-passers, police removal of drug users, house evictions and demolition in deteriorated buildings, and contentious and short-lived state policies with regard to the area. The second part of the article contrasts this experience with living and conducting research in Ouro Preto, a Brazilian UNESCO World heritage site where residents have long been established and have a strong sense of social cohesion. While, for me, the violence and disorder of Luz made conducting research there impossible, in a place like Ouro Preto, characterised by strong networks and familiarity, I ceased being an anonymous entity, which created its own challenges. Drawing on 15 months of fieldwork in these two distinct contexts, I discuss how researchers can face intimidation brought about by both distance from informants and excessive closeness, and how research questions and findings are often limited by such personal possibilities and positions.

Key words: Fieldwork, Crackland, Ouro Preto, methods, detachment, closeness. 


\section{Introduction}

The dimensions of closeness and distance, of 'how much is shared with the people being studied' (Strathern, 1987, p. 19), create possibilities and limits for ethnographic research. Researchers have to decide how much information and time are needed to approach their target location or group, and these decisions influence the outcome of their ethnography. Situations of both distance and closeness may create fear, discomfort and tension; or trust, empathy and friendship and such perceptions may change the interpretation of the object being studied. Commonly, however, closeness is an expected result of ethnographic encounters and distance from informants may be wrongly assumed to be more problematic for ethnographic writing, a polarisation this article aims to reassess.

In discussing how both distance and closeness to informants challenge ethnographers, I agree with authors such as Borneman (1992) that conflicting "truths" are the natural product of subjective vision in any field site. Thus, time and space are important variables when assessing the benefits or harms of both familiarity and reservation in ethnographic studies, especially in cities, which have multiple identities shaped by the researcher (Parsons, 2000). Because ethnography is embedded with one's own experience and subjectivity, it is crucial to assess how the field setting limits and reshapes the investigation methodologically.

My first case study stems from fieldwork in the Luz area of São Paulo in 2012. A commercial and transportation hub with often irregular and low-budget housing, Luz is also known as Crackland because of the prevalence of drug use in the area. In the 2000s Luz became central to urban discussions in São Paulo (Frugoli \& Skalair, 2009; Maquiaveli, 2012); chief amongst numerous actions was the Nova Luz Project [1], an ambitious programme to restore the area, which drew on memories of São Paulo's past - fine arts, education, and hybrid living in the city centre - to design future hopes for the area, despite a reality of neglect of central spaces (Maquiaveli, 2012, p. 152). As the project faded in the face 
of residents' resistance and rejection by the public and academics, speaking about Nova Luz with its developers became taboo. For this group of informants, much about Luz revolved around hidden interests, fear of negative repercussions in their personal or professional lives, and intimidation brought by the project's failure. The failure of the Nova Luz Project made many of my informants reserved and distant, unwilling to share time or information with me. Collecting data at a sensitive time for my informants also affected me, and I discuss the experience of isolation and some problems in the use of sensitive data with little sense of reciprocity (Johnson \& Clarke, 2003). In this context, I examine how ethnographic research based on interviews and participant observation confronts limits. I also consider how possibilities can arise in such contexts; new groups may open up while others retreat. Yet, discomfort, nuisance, tension, fear, and change were part of the experience in Luz.

I then discuss another fieldwork experience in 2013, this time in the city of Ouro Preto, Brazil. In that UNESCO World Heritage Site, 130 times less populated than São Paulo (IBGE, 2015), I observed the city centre's association with cultural heritage and cross-class housing and trade. In contrast with my experience in São Paulo, I faced "risky" closeness due to a highly identifiable social network. I use the word risky taking a moral dilemma approach (Fox, 1999), because although my experience was not connected to violence and danger, the strong cohesiveness of the city created situations where my role and behaviour as an ethnographer could directly impact on my informants (Nilan, 2002, p. 376). My informants lived in a 'friendship economy' where '[s]ocial networks [were] increasingly important to the economic survival of the working class' (Rebhun, 1999, p. 56); consequently, my relationships in the field and the relationships between my informants made me aware of the tensions brought about by my research. The confinement of a relatively small city made many people aware of my work before I met them, reflecting the descriptions of my informants of being excessively dependent economically and exposed to one another. Thus, I discuss how 
closeness does not necessarily make developing field relationships easier. In light of these experiences, I also address the importance of learning from others through self-knowledge and thus how reflexivity may help in gaining an insider's view (Nilan, 2002, p. 375-6).

\section{Walking the "Crackland" and studying the Nova Luz Project}

São Paulo, December 6, 2012: on my daily walk through the city centre today, I stopped to take pictures of a building being restored - this is one of the many buildings centrally located that are under a process of restoration, others have been demolished or occupied by housing movements - but the chief engineer interrupted me: "Hey, what are you photographing? You cannot take pictures of the building!" A police car passing by waited to see what was going on. I replied I was a student interested in urban re-development. The engineer requested my student card and after I showed it to him he lowered his tone. Seeing that I wasn't part of any social housing movement, the police drove off and the engineer invited me to see the project. I spent the afternoon in that construction site (From field notes, December 6, 2012).

In 2012, the government, housing movements, shop owners, drug users, long-term residents, and users of cultural offerings all had an interest in São Paulo's city centre and were wary of people who were interested in that area, called Luz and nicknamed "Crackland". For example, in 2011 and 2012, the top two newspapers in São Paulo published almost 300 articles directly related to the city centre, its urban redevelopment and aspects of criminal activity. Thus, the government faced escalating social and economic pressure to provide (some of) São Paulo's citizens and visitors with an appealing city centre, featuring buildings of historic value, cultural attractions, housing opportunities and commerce. While, to a certain extent, a vibrant, historic, residential and commercial centre already existed, the history of failed housing and business opportunities told through the crumbling facades of buildings did not appeal to middle-class residents or visitors. Instead, São Paulo's centre was mainly home 
to poor residents, mostly families who illegally occupied uninhabited buildings evacuated decades before when the upper-class moved from the centre to private condominiums on the outskirts (Caldeira, 2000). Some lower middle-class families also moved to old apartments in the centre to benefit from the easy availability of transport facilities. These families often shared run-down houses called cortiços, paying low rent in multi-family apartments. Commerce in Luz was mainly focussed on electronics with several owners setting up minishops within a single shop and sharing the rent. These shops which often violate sanitary and safety regulations, offer products cheaper than elsewhere in the city. In addition, the centre was home to the homeless, drug users and dealers, and prostitutes. Luz is also the site of the largest train station in the city, which led to crowded sidewalks strewn with too much litter for the municipality to collect, thus attracting informal litter collectors guiding large donkey carts. However, luxury cars and upper-class visitors could be seen on their way in and out of cultural centres - concert halls, art galleries and museums - installed in the area in the past decade to change its filthy appearance. This led to a growing number of police officers and private security in the surroundings of cultural centres to guarantee the safety of a few.

While government action was needed to improve Luz, the parties involved debated whether redevelopment should make the city centre appealing to new residents or provide adequate housing for those already present. Protests, occupations, newspaper reports, and academic debates reached a crescendo in 2012. However, instead of adding to my research data, some of the controversies around Luz made ethnographic data collection much more complex than anticipated.

In Luz, I hoped to assess the different expectations and uses of the area that co-existed, focussing on that specific zone and its endeavours in a given time (Borges, 2003), to then focus on a specific group of people. Mine was an attempt to map how Luz's users lived in that uncertain area at a time of planning and re-development, and to also understand the 
creative dimension underlying city planning as well as the contested interpretations and uses of buildings (Latour \& Yaneva, 2008, p. 86). To understand the new blueprint for the area, I used published material and interviews with the consortium of companies re-developing the centre. I also relied on participant observation to learn more about the housing, cultural and commercial situation in the centre, and conducted interviews with residents and shop owners. After mapping some conflicting expectations, I hoped to focus on planners as a key group of informants to find out how they imagined the past of the area, as well as its future and thus understand which space the present had in their view. I was also interested in knowing, as the project developed, how such re-development affected them in particular, thus focussing on their place-making (unmaking and remaking) in town in relation to the project. However, reaching this stage was particularly challenging.

When I approached the consortium of construction companies in the second half of 2012, much about the Nova Luz project had become chaotic. Gaining access to the urban planners in charge, recording data and maintaining contact became difficult as the debate between businesses, the media and residents intensified. Recent attempts to demolish buildings, divisive police action to expel crack users and the suspension of the project due to the lack of public hearings brought the project into direct confrontation with local users. In addition real estate speculation, which would mean more profit for the consortium, came too early and meant higher costs for investors. More problematic, however, was the fact that 2012 was a year of municipal elections and with so much controversy around Luz the project was under political attack. For these reasons, during interviews I found myself witnessing the developers' struggle to implement the project or simply save their careers.

The handful of people representing the consortium of companies in charge of the Nova Luz project held much of the responsibility for designing some of the project's main actions and addressing local residents and the media; as such, they also faced the negative 
repercussions. I was able to interview key representatives of the consortium involved in the project, but some suggested I leave the programme while I could. I had a sense they would also leave if they could. They often explained their role in the project in a defensive tone and I grew aware of my academic position. Introducing myself as a Brazilian researcher put me in the group of opponents to the project. One of my interviewees from the consortium of companies explained that academics were against the project, especially because private companies, and not only the government, would be able to expel residents (a radical change in Brazilian urban development). My Brazilian nationality and profession thus jeopardised a possible trust relationship. However, the same interviewee mentioned that she had not previously been visited by academics and my visit created some sense of credibility. In addition, the fact that I was pursuing my studies overseas meant that I was not coming from a clearly known position. In short, I had neither the bias a local researcher would have, nor could I 'get away with asking ignorant questions (...) [and] be treated with as much tolerance' as foreigners in Brazil may experience (Rebhun, 1999, p. 4). I negotiated my space, reassessing my identity in the field throughout conversations.

The interview partners leading the Nova Luz Project also shared with me the complex situation on the ground. They explained that the group opposed to the project also included wealthy traders and property owners who profited from the decay in the area by unlawfully accommodating additional people in residential or commercial units. Wealthy home owners elsewhere in São Paulo also opposed the project as it might set the precedent that any neighbourhood could be considered misused and targeted for change. The consortium also agreed that different political agendas underlay the position of the participants in this discussion. The political party then in charge was not historically associated with social housing and thus expelling residents would always be targeted as gentrifying, no matter how many social housing units would be later created. This political situation, in addition to the 
project's schedule (also set politically), challenged its implementation and reaction to it.

These interviews demystified some negative views on the project while also connecting me to my informants in a very unusual way. There was a degree of empathy for my work and willingness to contribute, but this was followed by narratives of a lack of control of the project's course, which sometimes literally translated as advice to give up or change my project, ultimately turning our proximity into distance. I tried to approach other key informants before deciding what to do about this "proximity-distance" relationship.

Establishing more continuous relationships with informants in the Luz area itself was equally difficult. The leader of the shop owners' association explained that they were against the Nova Luz project because it included eviction and demolitions and was time-consuming estimated to last 15 years - but they were not against any revitalisation for the area. This aimed to defend the position of the shop owners against criticism voiced by the consortium of companies. However, the shop owners' did not facilitate my study of the area as they considered my research unsafe, because it would assess different interests and stakeholders, and advised me to leave.

Talking to residents also had its limitations. In an area with many commuters, it was hard to find those living there and we did not have a neighbourly relationship. As a single woman, student, middle-class and white, or whitened by education and class (Sheriff, 2011, p. 72-3; Wilson, 2007, p. 68; Souza, 2010, p. 188), a short-term letting agreement in that area was suspicious. Most property owners in São Paulo have great demand for their properties and select their clients based on the length of the contract (usually a minimum of 36 months), preferring to rent units to families and males. In this housing market, single woman looking for short-term letting are suspected of being mistresses or prostitutes. In the city centre this problem was intensified as this area was already associated with prostitution. However, my experience in middle- and upper-middle class neighbourhoods wasn't much different. 
Searching for a flat occupied much of my first months in town and I did not live in Luz, but in an affluent neighbourhood with buildings mainly catering for the business community and open to me (with less suspicion). Females facing problems in urban ethnography in Brazil is well documented (Goldstein, 2003; Wilson, 2007), as is how class intertwines with every aspect of social life in the country (O’Dougherty, 2002; Owensby, 1999). The combination of gender and class issues meant that the decision on my housing location did not solely belong to me.

While commuting daily to my field site I visited the project's local office, which offered explanations of the project to anyone who walked through the open doors, though local residents rarely stopped by. One group of residents that was open to me were members of housing movements camping outside or in decayed buildings. Often, after talking to them and returning for a second and third meeting, I found my interview partners gone, removed by the police or relocated to social housing elsewhere. After a few visits, however, I got to know some of the occupiers well. I had access to occupied buildings, mainly run by families who often had their water or electricity cut by the state to counter occupations, but who displayed impressive long-term planning. They invited me to occupy an empty building with them, so that I would understand the way they organised the occupation and later distributed families. I agreed that the experience was important, but the prospect of knowing when and which building they would occupy made me insecure about the criminal nature of this endeavour. Though many researchers feel the need to overcome personal moral and ethical demands in the name of ethnographic relationships and in some cases for survival (Rodgers, 2001), I was not sure whether I would be prepared to put myself at personal risk of a confrontation with the police and private guards. Finally, if the police anticipated their act, would my informants think I was the whistle blower? I also feared that the invitation could jeopardise recently established field relationships with engineers and construction workers in the area (who lost 
jobs when buildings were taken by assault) and with the city planners and, potentially, even the one with the housing movements. I declined the invitation. The next morning, I read in the news that, while they were attempting to occupy the building, private guards shot at occupiers and some of my informants were wounded.

Thus, the only group of people that opened up to me in the field, through which I could find out more about the Nova Luz Project, was also the group I found most difficult to follow. Much of their activities consisted of planning occupations or occupying buildings that could be a target for police action at any given time. In practical terms, understanding the housing struggle and regeneration project in São Paulo from their perspective meant having a group of informants who moved houses (or were removed) and were difficult to keep track of; occupying buildings was also both personally frightening and unlawful. Finally, housing movements existed before the project and extended beyond the city centre; as a result their concerns were about broader economic and social issues than the Nova Luz Project itself.

After five months in the field, I decided to leave São Paulo. Adding strength to my resolve was the surprising political decision to discontinue the Nova Luz Project as an outcome of the mayoral elections. The elections were a common topic with interview partners and nobody anticipated the end of the project but changes to it. However, when the new mayor of São Paulo took office in January 2013, stopping the project was one of his first public announcements. A few days later the website with all the information material demographic studies, reports on public meetings, economic and urban prospects for the area, pictures, and videos, amongst others - was no longer available. Hopes for a new city centre were still part of the São Paulo scene; however, no major development projects would follow.

Investigating a location at the time of an on-going contentious project was a key interest. It presented me with many challenges including competing perspectives, hidden political and economic agendas, legal and safety concerns and a shared insistence that I 
should not be there, until the project was finally disrupted. The insistence by some informants and friends that I should give up on the Luz area was particularly challenging and a key limitation. For the developers I wanted to learn from, my questions were a reminder of contested planning, and later a failed one. When the project was stopped, investigating why it failed became untenable because the Nova Luz Project was a sensitive memory some of my informants preferred to forget, or a memory narrated in tears.

The provisional title of my research project in Luz was: "Memories of São Paulo: Perceptions of class and city space in the Nova Luz Project". However, instead of sharing memories of Luz, most of my informants that were key stakeholders in the project needed some distance from their ties with the area; this imposed a distance between us. While the importance of forgetfulness in society has been addressed theoretically as a topic that is as important as remembrance (Sheriff, 2001, p. 62), it is more difficult to study it using participant observation and interviews. Writing about what has not happened can be an interminable process (Miller, 2003), because waiting until remembrance of a failed project no longer harms the narrator's present can impose a long delay (Farage, 2003). In Luz, even people who benefited from the end of the project were waiting to see what would replace it, and to them too the project was still taboo. It is thus not surprising that most published research on Luz focuses on drug users (Rui, 2012; Frugoli \& Spaggiari, 2011), the urban space itself (Frugoli \& Sklair, 2009; Jose, 2010; Monteiro, 2009) and cultural offerings (Moreira, 2008), with a clear lack of attention to policy makers in that space. In a site marked by a sequence of frustrated urban plans there are also frustrated researchers who do not have immediate access to stories about failure.

When my interviews with informants induced painful memories and violent emotions, I found that this was a limit to research that I could not respect myself for crossing. Together, the end of the project and the elements leading to its failure made Luz greatly disrupting as a 
vehicle of ethnographic knowledge and it created distance between myself and my informants, making it difficult to ask them questions. This is not to say that research in Luz or in places facing great social disruption, policy-making failure and political instability is unattainable for researchers. Indeed, it is both possible and necessary. For places like the Crackland there is also a growing body of ethnographic work focussing on 'disorientation' as a research method (Spissu, 2017). Whether getting lost may be a necessary moment of any ethnographic research which allows for 'fresh viewpoints' (ibid, p. 20), or a key method throughout an ethnography, often leading to a self-reflected text (Canevacci, 1996), a PhD thesis is not always the best place for a methodology mainly focussed on disorientation or self-reflection. During a PhD, researchers face a combination of limited field experience and time and financial constraints (Johnson \& Clarke, 2003; Herzfeld, 2013). In addition, lack of control over experiments in association with isolation brought about by great social and political disruptions commonly lead to mental distress amongst researchers (Levecque et al., 2017). The combination of these elements meant that I started 2013 exploring alternatives for my proposed research questions.

To continue pursuing a research agenda exploring how public policies for city centres are implemented, perceived and experienced locally, I moved to the city of Ouro Preto. The city centre of Ouro Preto is a role model in Brazil. This hybrid location brings together local residents, tourists, students and workers who use the centre for leisure and services. Ouro Preto's centre has also been preserved as a national monument for decades and the proximity with residents, policy makers and traders would be one of neighbourliness rather than negotiated access, discontinuity and distance. What I did not anticipate, however, were the challenges of proximity.

\section{Ouro Preto: social closeness and economic dependency in a context of urban disputes}


We sat around the kitchen table and I explained to Silva that I could no longer sublet a room in his house because I grew allergic to the mouldy walls. This was a real health problem and easier to explain than my wariness to his alcoholic abuse. Silva was uneasy. He called my mother, whom he had met a few weeks before, and told her I was leaving his house and was no longer "his responsibility". I never felt under his responsibility, but accepted this as a caring farewell. However, things turned less fond when we needed to discuss the outstanding payment for my stay. Silva could not remember I had already paid for the Internet and anticipated part of my rent as when I paid for grocery; he wanted the full sum. I resisted because the amount was already well above the average price in town and showed him some written notes and bills thus unintentionally offending his pride. After a long and difficult conversation, we compromised on a sum and I entered my room to pack. I was surprised when some minutes later Silva knocked on my door and gave me a little box with three semiprecious gems. He explained I should take them abroad and tell all my friends in Europe about the beautiful gems he sells in Ouro Preto. He told me the best was to not let me leave his house upset with him, an opinion I shared, I knew well that both our businesses in town relied on social relationships (From my field notes, June 2013).

Ouro Preto, a city in the southeast of Brazil, has maintained its city centre in a relatively preserved state since its designation as a national monument in the 1930s. This was reinforced when the city was hailed as a UNESCO World Heritage Site in 1980 for its aesthetic and creative architecture. It is also a centre for higher education (universities) and culture (music, painting, and soapstone art and craft, amongst others) and the downtown area is used in multiple ways - commerce, housing, open festivals and so on. Thus, Ouro Preto is a city where most people are transiently present (tourists, students and temporary workers) and those who are permanent residents usually know one another well.

The level of proximity amongst residents in Ouro Preto can be very surprising for those coming from larger cities, as in my case. Trust amongst residents facilitates everyday life, such as grocery shopping with a tab to be paid later in the month. This level of trust and 
neighbourliness impressed me at first. Later, however, I realised how informality allowed businesses to survive. In an economy where customers are unpredictable, many shop owners experience months of deprivation and residents depended on a social network for jobs, housing or a tab in the supermarket. However, these same residents who depend on one another also compete for clients, because most offer similar services in tourism, hospitality or gastronomy. A relationship of competition and dependency in Ouro Preto, also described in larger cities (Simone, 2004), means that in city conflicts most residents will not publicly voice their concerns for fear this would disrupt their social and economic chain.

Housing is a major concern in the city. Most centrally located and preserved houses cater for temporary residents (students and tourists) while permanent residents live in a temporary city - improvised houses on the slopes of hills. Landslides are common during periods of heavy rain and the houses are at risk of being demolished in terms of the city's strict regulations due to its preservation status. Poorly constructed houses are often far removed from preserved areas while remaining visible from the city centre. Other conflicts include mining, as the preserved city lies atop mineral deposits. The tension around mining, preservation, housing, infrastructure and taxes is of enormous importance.

Mining means jobs for some people while for others it means pollution, traffic congestion and displacement. Public participation is used to resolve competing interests (Caldeira \& Holston, 2005; Andrade dos Passos, 2010; Cornwall \& Shankland, 2013). In Ouro Preto issues revolving around cultural heritage, jobs, houses and the landscape are discussed in grassroots meetings of members of civil society and technicians - known as conselhos municipais. However, when residents (mainly poor, with informal jobs and housing) negotiate with local government and large companies, they usually do so in fear of confronting established power; this is expressed in the saying: 'those who command do so because they can; those who obey do so because they are sensible [2].' Despite being open 
forums such meetings are not for everyone because,

[t]he upper classes, by virtue of their position, can deploy their weapons directly (in the form of economic and political control, for example). The poor, by contrast, are forced to express their resistance behind the backs of power (Goldstein, 2003, p. 7).

My ethnography was thus an act of attending public meetings directing local heritage policies while also looking at what was not publicly voiced, because often residents were either silent or absent. Ethnographic writing in this context is a powerful tool to extend such meetings beyond the meeting rooms and explain what may linger unsaid. But it is also an unrehearsed exercise in how to expose issues without exposing one's informants.

In Ouro Preto, frustration with local policies seldom takes the form of protests, newspaper headlines or occupation of central houses and public spaces, as it does in São Paulo and other larger cities in Brazil. Instead, as one of my interview partners explained, "everybody is afraid to talk in Ouro Preto".

Thus, in Ouro Preto I also found silence to be an important ethnographic variable, especially in public meetings. While in São Paulo silence (the attempt to be dissociated from the Nova Luz failure) was related to unpredictable changes threatening the informant; it was the prospect of continuity in an entwined social network that prevented some residents in Ouro Preto from publicly voicing their demands. In heritage meetings, the conflicts around preservation often reached a consensus that did not exist beyond the room because extending negotiations was more threatening than agreeing on a suboptimal decision. The same residents who complained to me about their situation in informal conversations or interviews would not necessarily voice opinions when given the opportunity to direct local politics. Protests or publicly voicing issues in open meetings was a privilege for those with permanent houses and 
employment who did not depend on social and kinship ties for work or in the management of the housing shortage. But even this group often vacillated, as conflicting situations in a city where everyone knows everybody else may compromise friendship.

From the perspective of some of my informants, I was in a privileged position. Coming from a larger city with an academic and economic background above the average, and standing outside the close connections tying residents together, I did not depend on anyone in town for a job or housing. However, because my informants were also my friends and hosts, they placed a lot of trust in me in letting me into their private and professional lives, and any disputes with local economic and political establishments could affect those who were associated with me. As I became known personally within the community, I was simultaneously positioned and perceived within the pre-existing networks of my hosts and friends. Thus, I started to gain knowledge about my informants and field site by reflecting about my own situation of social dependency (Strathern, 1987, p. 27).

Silence or avoidance of public confrontation presents an ethnographer with numerous questions. They are hard to interpret because it is unclear if silence is an act of defiance or is inspired by fear of repercussions. However, for some of the questions, I found answers through my own experiences in town. While residents in larger cities in Brazil show a 'new conviction about citizenship among the working class', with individuals voicing their own rights over those that occupy a higher-rank (Holston, 2008, p. 17), I experienced the following social encounter in a public space in Ouro Preto:

In the afternoon of October 15, 2013, I arrived at a public building and waited for my appointment. In the same waiting hall and sitting opposite of me, there was a woman smoking quietly. After a long waiting time, and annoyed by the smoke clouding in the hall, I asked the receptionist if it was permitted to smoke inside public buildings and he replied, to my surprise, "no problem." The smoker heard my question, but continued 
smoking, however, now looking intensely at me. The staring was threatening and I read on my phone to avoid eye contact. I looked up smoking laws to find out smoking was forbidden where we were. A few minutes later the receptionist went outside to smoke. I asked him "if you allowed that person to smoke inside, why did you come outside?" His answer was short, "of course it is not legal to smoke inside, except if you are the prosecutor" (From field notes, October 15, 2013).

In that social encounter, the result of long hours of waiting in public buildings, I was silent against inequality and breaking the law. At this point, I could position myself as an ethnographic subject rather than the ethnographer and reflect on my own experience as a resident in Ouro Preto. In a city with less than 80,000 inhabitants, and with only a small number of those working in public administration, I would probably see that woman again. My work in town depended to a great extent on my social relationships and was sensitive to disputes in the short run, as I was about to go to a meeting with one of the woman's colleagues. In the long run, living and working in a place where everybody knows everyone else. I was discouraged by the potentially negative social consequences and a lack of hope in achieving any result, especially because all this happened in a location where one goes to seek justice. Holston (2008) recognises a difference in social encounters between 'anonymous others' and people who 'know each other in a variety of employment and servant relations' ( $\mathrm{p}$. 276). In such encounters disputes about rights may not happen through a 'direct verbal confrontation' (p. 277).

While being in a small city granted me access to a variety of informants, it was also problematic because people were unwilling to disrupt the long-term social relationships they depend on. This led to my informants having a private and a public opinion, and being afraid to voice the former. I also found myself forming private and public opinions. This became clearer when I was pressed to advocate for residents during negotiations with powerful mining companies. I was at the same time a researcher and a subject who became part of the 
town's network and whose actions had consequences for both my ability to work there and for the people associated with me. This perception of intimidation became an important variable in my ethnographic research.

Doing urban ethnography in a location such as Ouro Preto, the ethnographer's decision of who to associate with becomes much more impactful, because in such a tight network associating with some people means alienating others. While many anthropologists work in villages smaller than Ouro Preto, working in a small city in my own country implied a level of continuity between researcher and research site. I expected to return and share my findings (Strathern, 1987, p. 17) and did not have the security of those writing to an 'exclusive domain' (p. 20). In cities like Ouro Preto not only do the researcher's actions reflect on his or her contacts but also the other way round. For example, one of my informants, knowing that I was interested in listening to a variety of opinions in town, set a meeting with me in a neighbouring city. We had to commute because he said that if people in town saw us having a conversation his opponents would no longer speak to me. When my informants protected me in such ways I often felt the need to reciprocate by protecting them. I grew aware of where I would set our meetings and how I would publish my findings. I was no longer anonymous in town nor could my results be anonymised in a city of highly identifiable subjects and events (Goldman, 2013). Being in the field and publishing my findings thus involved considering the complex relationship of social dependency typical of Ouro Preto. Self-reflection and attention to artistic expressions of residents such as hip-hop music and story-telling and everyday participant observation gave me public references that I could use to talk about unvoiced private opinions. Speaking to informants after events of "public silence" or double-checking with them the material gathered in interviews were ways to make myself and my informants feel more comfortable about using my data. The willingness of most my informants to talk to me and let me publish the material of our interactions, despite tensions in public meetings, 
shows the importance of ethnographic work in understanding public interactions. What happens before and after public encounters (assemblies, protests, cultural events) is often more telling than the occasions themselves (Nilan, 2002, p. 384), because ordinary people do not always have the privilege of political participation when the struggle for survival takes precedence over representative exercises (Appadurai, 2013, p. 79; Goldstein, 2003, p. 7). The informants' willingness to participate in my research also shows that writing has a different impact on local relationships from verbal confrontations, the first being considered "more distant", however more telling and permanent it might be.

The situation in Ouro Preto mirrored that in São Paulo with their contested central spaces, although the two cities were also inversions of each other. In São Paulo, people publicly expressed their interests (protests, occupations, policies and resistance to them) and did not necessarily open up to an ethnographer when speaking about local controversies. In Ouro Preto, the blur between the researcher and the informant allowed me to continue my research while also creating uneasy personal relationships. Indeed both proximity and distance created risky situations, pressing me as the ethnographer into making methodological, moral and ethical decisions.

\section{Conclusion}

In the field I experienced a situation where being close meant being distant. As I became close to my informants in São Paulo they encouraged me to distance myself from the Nova Luz Project. By knowing urban planners I learnt to respect the end of a project they invested much of their time in and the distance it imposed between us. In contrast, I became closer to my interview partners in Ouro Preto and we shared the experience of being co-dependent. However, nearness is not to be confused with easiness. I wrongly assumed that closeness would mean less disruption in data collection. In a country such as Brazil, with cities scarred 
by social and economic inequality, violence and political disruption, ethnographic research requires that one faces this tension. A careful fieldwork choice cannot guarantee an ease for researchers that does not exist for those being investigated. However, some research questions and situations may add to the perception of risk or may cause discomfort and embarrassment among informants and researchers alike and the ethnographer needs to be aware of this when planning a study.

In São Paulo, my presence, questions and observations added to the anxiety of some of my informants when talking about a highly controversial project. There were also those who felt comfortable with my research, such as the housing occupation movements, but personal and research limits prevented me from greater interaction. In Ouro Preto, perceptions of intimidation were part of the experience of residents in town, but this was not brought on by my research. My experience in Ouro Preto allowed me to understand why direct confrontation may need to be avoided and how new means of participation in city plans may arise, which include storytelling and creative writing, hip-hop music, social media interaction and radio, as well as private conversations, all of which are non-confrontational vehicles of communication. When the researcher impacts the field and the field the researcher, to write reflexively on this relationship may not always be enough. It is also necessary to use reflexivity to gain the informants' views and thus to use research in a way that is beneficial for researcher and informants alike (Marks, 2005, p. 86-7). In São Paulo, reciprocity between researcher and researched did not exist; I could understand the Nova Luz Project through my informants, but the best I could offer them, at that moment, was my distance. In contrast, the level of reciprocity in Ouro Preto meant listening to what my informants had to tell me and writing about it, while respecting their avoidance of publicly voicing their opinions in significant local urban disputes. Ethnographic writing was not only welcomed in town, but it also added information on why participation still works piecemeal and heritage is not yet a 
popular endeavour. New tools to expand discussions beyond direct participation are being discussed in Ouro Preto as a result of my investigation.

\section{Notes:}

1. The Luz area is a polygonal around the Luz train station - the largest in the city - and has a population of more than 11,000 people. The housing re-development project, with attention to cultural and trade schemes, begun to take concrete shape in 2009 , when a law of urban concession was approved. The proposed Luz redevelopment revolved around a model of an urban concession to a consortium of construction companies. The idea was based on the consortium's right to evict residents of specific buildings, demolish some structures and construct new ones that could be sold for profit. In exchange, the consortium had to improve Luz in accordance with a plan agreed upon by City Hall, which included the design of sidewalks, green parks, libraries and other amenities for the city and its inhabitants.

2. My interview partners in Ouro Preto often repeated this Brazilian expression, which in Portuguese is "manda quem pode, obedece quem tem juízo". I use the translation that Goldman (2013, p. 54) uses in his book about politics in Brazil.

\section{Acknowledgments}

I thank the University of St Andrews for the support during ethnographic research in Brazil and the Russell Trust Travel Award, Scottish Funding Council and University of St Andrews for financing the fieldwork and $\mathrm{PhD}$ research. My thanks to all informants in both field sites who made my research possible. I wish to thank Alexander Mielke and three anonymous reviewers for valuable comments, and Dr Julten Abdelhalim and Professor Monique Marks for organising this series. 


\section{References}

Andrade dos Passos, L. (2010). Planejamento urbano e participação da população: labirinto democrático? Unpublished $\mathrm{PhD}$ Thesis, Department of Architecture and Urbanism, University of Brasilia, Brasilia.

Appadurai, A. (2013). The Future as cultural fact: Essays on the global condition. London: Verso.

Borges, A. (2003). Tempo de Brasília: Etnografando lugares eventos da política. Rio de Janeiro: Dumara Distribuidora.

Borneman, J. (1992). Belonging in the two Berlins: Kin, state, nation. Cambridge: Cambridge University Press.

Caldeira, T. (2000). City of walls: Crime, segregation and citizenship in São Paulo. Berkeley: University of California Press.

Caldeira, T. \& J. Holston (2005). State and urban space in Brazil: From modernist planning to democratic interventions. In A. Ong \& S. Collier (Eds.), Global Assemblages: Technology, Governmentality, Ethics (pp.393-416). London: Blackwell.

Canevacci, M. (2004). A cidade polifonica: ensaio sobre a antropologia da comunicação urbana. São Paulo: Studio Nobel.

Cornwall, A. \& A. Shankland (2013). Cultures of politics, spaces of power: contextualizing Brazilian experiences of participation. Journal of Political Power, 6(2), 309-333.

Farage, N. (2003). Rebellious Memories: The Wapshana in the Rupununi uprising, Guyana, 1969. In N. Whitehead (Ed.), Histories and historicities in Amazonia (pp. 107-120). Lincoln and London: University of Nebraska Press.

Fox, N.J. (1999). Postmodern reflections on risks hazards and life choices. In D. Lupton (ed.), Risk and Sociocultural Theory. Cambridge: Cambridge University Press.

Frugoli, H. \& Skalair, J. (2009). O Bairro da Luz em Sao Paulo: Questões Antropológicas Sobre o Fenômeno da Gentrification. Cuadernos de Antropologia Social, 30, 119-136.

Frugoli, H. \& E. Spaggiari (2011). Networks and Territorialities: an ethnographic approach to the so-called cracolândia [“crackland”] in São Paulo. Vibrant, 8(2), 499-579.

Goldman, M. (2013). How democracy works: An ethnographic theory of politics. Herefordshire: Sean Kingston publishing.

Goldstein, D. (2003). Laughter out of place: Race, class, violence and sexuality in a Rio shantytown. Berkeley: University of California Press.

Herzfeld, M. (2013). Cryptocolonialism, the responsibility of the social sciences and Europe. Johannes Lenhard and Raffaella Taylor-Seymour interview In Kings Review, (available online: http://kingsreview.co.uk/articles/an-interview-with-michael-herzfeld-cryptocolonialism- 
the-responsibility-of-the-social-sciences-and-europe/, accessed March, 1, 2017).

Holston, J. (2008). Insurgent citizenship: Disjunctions of democracy and modernity in Brazil. New Jersey: Princeton University Press.

Instituto Brasileiro de Geografia e Estatística (IBGE). (2015). Cidades: Ouro Preto (available on-line: http://cidades.ibge.gov.br/xtras/perfil.php?lang=\&codmun=314610\&search=minasgerais|ouro-preto|infograficos:-informacoes-completas, accessed December 8, 2015).

Johnson, B., \& J., M. Clarke (2003). Collecting sensitive data: The impact on researchers. Qualitative Health Research, 13(3), 421-434.

Jose, K. (2010) A popularização do Centro de São Paulo: Um Estudo de Transformações Ocorridas nos Últimos Vinte Anos. Unpublished PhD Thesis, Department of Urban and Regional Planning, University of São Paulo, São Paulo.

Latour, B., \& A. Yaneva (2008). Give me a gun and I will make all buildings move: An ant's view of architecture. Explorations in architecture: Teaching, design, research, 80-89.

Levecque, K. Anseel, F., De Beuckelaer, A., Van der Heyden, J., \& Gisle, L. (2017). Work organization and mental health problems in PhD students. Research Policy, 46(4), 868-879.

Maquiaveli, Janaina. (2012). Passando a limpo: um passeio pelos processos e pelos projetos de revitalização urbana do Meatpacking District, em Nova York, e da Região da Luz, em São Paulo. EURE (Santiago), 38(115), 137-158.

Marks, M. (2005). Transforming the robocops: Changing police in South Africa. Pietermaritzburg: University of KwaZulu-Natal Press.

Miller, R. (2003). Here's the deal: The making and breaking of a great American city. Illinois: Northwestern University Press.

Monteiro, L. (2009). Moradia Social: Ocupação de Espaços Desconstruídos Livres. Unpublished Master Thesis, Department of Urban Engineering, Federal University of São Carlos, São Paulo.

Moreira, C. (2008). Intervenções Urbanas Contemporâneas: o Caso da Area da Luz no Centro de São Paulo. Unpublished PhD Thesis, Department of Architecture and Engineering, University of São Paulo, São Paulo.

Nilan, P. (2002). 'Dangerous fieldwork' re-examined: the question of researcher subject position. Qualitative Research, 2(3), 363-386.

O'Dougherty, M. (2002). Consumption Intensified: The politics of middle-class life in Brazil. Durham: Duke University Press.

Owensby, B. (1999). Intimate Ironies: Modernity and the making of middle-class lives in Brazil. California: Stanford University Press.

Parsons, D. (2000). Street Walking the Metropolis: Women, the City and Modernity. Oxford: 


\section{Oxford University Press.}

Rebhun, L. A. (1999). The heart is unknown country: Love in the changing economy of northeast Brazil. Stanford: Stanford University Press.

Rodgers, D. (2001). Making danger a calling: Anthropology, violence and the dilemmas of participant observation. Working paper for the Crisis States Programme, London School of Economics and Political Science, London.

Sheriff, R. (2001). Dreaming Equality: Color, race and racism in urban Brazil. New Jersey: Rutgers University Press.

Simone, A. (2004). People as infrastructure: intersecting fragments in Johannesburg. Public Culture, 16, 407-429.

Souza, J. (2010). Os Batalhadores Brasileiros: Nova classe media ou nova classe trabalhadora? Belo Horizonte: Editora UFMG.

Spissu, G. (2016). The familiar labyrinth: practicing urban disorientation in post-apartheid Cape Town. Anthropology Southern Africa 39.1, 14-30.

Strathern, M. (1987). The limits of auto-anthropology. In A. Jackson (Ed.), Anthropology at home (pp. 59-67). London; New York: Tavistock Publications.

Rui, T. (2012). Corpos Abjetos: etnografia em cenários de uso e comércio de crack. Unpublished PhD Thesis, Department of Philosophy and Human Sciences, University of Campinas, São Paulo.

Wilson, M. (2007). Dance lest we all fall down: A journey of friendship, poverty, power and peace. Tennessee: Cold Tree Press. 